Kunt, Gergely. "Ironic Narrative Agency as a Method of Coping with Trauma in the Diary-Memoir of Margit K., a Female Holocaust Survivor." Hungarian Cultural Studies. e-Journal of the American Hungarian Educators Association, Volume 7 (2014): http://ahea.pitt.edu DOI: 10.5195/ahea.2014.137

\title{
Ironic Narrative Agency as a Method of Coping with Trauma in the Diary-Memoir of Margit K., a Female Holocaust Survivor ${ }^{1}$
}

\author{
Gergely Kunt
}

\begin{abstract}
This paper analyzes the rhetoric of a manuscript written in Budapest immediately after the Holocaust to record the personal experiences of the author, Margit K. I examine the text in terms of the role of writing and narration in processing trauma and how these appear in the narrative. In her memoirs, Margit K. had imbued her personal history of persecution with meanings that facilitated their integration into her life history and her self-definition. She chose to narrate her tragic past using euphemistic, mitigating, or ironic language and constructed her stories to have positive outcomes while attempting to write as little of the pain and tragedy of her persecution as possible. The euphemizing narrative methods used in the memoirs disappear entirely in the diary and the themes discussed in the diary are also different, which shows the advantages of constructing a desired past within the genre of the memoirs in contrast to the more strictly defined genre of diary-writing. However, these memoirs of the past stand in sharp contrast with the rhetoric of her diary concentrating on the present, where Margit K. writes in greater detail of the horrors of her everyday life following the liberation of Budapest and without any trace of the euphemisms characteristic of her memoirs.
\end{abstract}

Keywords: Narrative Strategies, Memoirs, Gendered Life Writing, Trauma, Hungarian Holocaust, Jewish Laws

Biography: Gergely Kunt, a social historian and Lecturer at the University of Miskolc, Hungary, teaches the social history of Hungary and East Central Europe. His dissertation on social ideas and prejudices during World War II was based on a comparative analysis of Jewish and Christian adolescent diaries. He has been collecting privatelyowned diaries and has acquired a great number of unpublished diary manuscripts from the period of the Holocaust. His papers based on these unpublished sources have been presented at several international conferences.

${ }^{1}$ This research was supported by the European Union and the State of Hungary, and co-financed by the European Social Fund within the framework of the National Excellence Program (project code: TÁMOP-4.2.4.A/ 2-11/12012-0001). 
Kunt, Gergely. "Ironic Narrative Agency as a Method of Coping with Trauma in the Diary-Memoir of Margit K., a Female Holocaust Survivor." Hungarian Cultural Studies. e-Journal of the American Hungarian Educators Association, Volume 7 (2014): http://ahea.pitt.edu DOI: 10.5195/ahea.2014.137

This paper analyzes the rhetoric of a manuscript written in Budapest about the Holocaust experiences of a Jewish female survivor, Margit K. The paper analyzes narrative methods and procedures from the perspective of their role in processing Margit's trauma, and therefore I focus on the rhetorical devices she used to describe her experiences rather than on the actual details of her survival during the German occupation of Hungary and the siege of Budapest. Margit's typescript can be found in the Budapest Collection of the Szabó Ervin Library in Budapest under call number BQ 0910/374; the over two hundred and seventy page typescript is comprised of three parts, an introduction followed by Margit's memoirs and finally, her diary. The manuscript begins with a five-page long introductory letter written by Margit and it tells us that she began writing her memoirs in March 1945 to recount her experiences between April 1944 and February 1945, the period of German occupation and the Soviet occupation of Budapest. She dedicated her memoirs and diary to her husband, who was forced into Jewish labor service in April 1944, and also stated that her reason for writing down the events of the previous year in March 1945 was to inform her husband of her experiences in order to fill the gaps caused by their separation. The introduction is followed by two hundred pages of memoir in which the author narrates her experiences between April 1944 and February 1945. Margit herself refers to this part of the text as a posthumus napló ['posthumous diary'], which sets it apart from the seventy-page diary she kept from February 1945 (the liberation of Budapest) until April 1945. The latest date in Margit's typescript is May 10, 1945, which either indicates the date of the conclusion of the original manuscript or refers to the date when Margit finished her typescript. Margit does not mention herself in her text by name and refers to herself as Kiskas ['Little Hive'], a nickname used by her and her husband. Her full name is only revealed at the end as she signed her work by hand on the above-mentioned date. Her signature not only denotes her authorship but is also an indication that "[i]t is impossible for the autobiographical vocation and the passion for anonymity to coexist in the same person" (Lejeune 1989, 20).

Margit, author of the typescript examined in this paper, was a thirty six-year-old Jewish woman living in Budapest during World War II, and in accordance with the Hungarian Data Protection Act, her anonymity shall be preserved by the use of her given name and the initial of her surname only. According to the statistics of the 1941 census $^{2}$ and Margit's school register ${ }^{3}$ found in the Budapest City Archives, her parents were born in the first half of the 1870s. Her father was an officer of the First Hungarian Economic Machine Factory and father of two children, with Margit born in 1909 and her younger brother Dénes born in 1911. The assimilated family claimed themselves to be Jewish Hungarians as suggested by the fact that their surname had likely been hungarianized and neither child had been given a name from the Old Testament, and while we know nothing of the younger brother's education, the insignificance of religious values can be discerned from the fact that Margit was sent not to a Jewish institute but to a state

${ }^{2}$ Budapest Főváros Levéltára (Budapest City Archives) IV. 1419/j. Documents of the Statistics Office of Budapest. Documentation of registration and processing documents of the 1941 census in the city of Budapest, Register 220/II (District III, Kecske utca 30.)

${ }^{3}$ Budapest Főváros Levéltára (Budapest City Archives) VIII. 33. b. Documents of the Budapest Veres Pálné Highschool for Girls affiliated with the Hungarian Association for Female Education, 267-272, school registers for the school years $1920 / 21$ to $1925 / 26$. 
Kunt, Gergely. "Ironic Narrative Agency as a Method of Coping with Trauma in the Diary-Memoir of Margit K., a Female Holocaust Survivor." Hungarian Cultural Studies. e-Journal of the American Hungarian Educators Association, Volume 7 (2014): http://ahea.pitt.edu DOI: 10.5195/ahea.2014.137

school and attended the Veres Pálné High School for Girls, where she completed her secondary school matriculation exams in 1926. By 1941, she was an official employee of the Hungarian General Credit Bank and it is presumed that she joined the bank after her graduation as a clerk. According to the school register, in the first half of the 1920s, the family lived in Váczi street in the inner city of Pest, and the 1941 census states that in 1928 they moved into an average threeroom middle-class apartment in Kecske street, Buda. In 1941, Margit's younger brother Dénes was registered as Roman Catholic rather than Israelite ['izraelita'] but the other members of the family had retained their religious affiliation. Dénes worked as a metallurgic meter reader, a rather unusual physical profession in a family of office employees that may have been chosen due to the pressure exerted by the anti-Jewish laws of the era.

We do not know for certain when Margit had changed her religious affiliation from Israelite to Evangelical [Lutheran], but the 1941 Hungarian census registered her as an Israelite and, according to her memoirs, Margit was forced to leave her apartment in Kecske street, Buda in June 1944 and move to a designated house marked by the Star of David in the inner city of Pest, where she lived until November 1944. During her stay, she managed to become a caretaker for the Red Cross with the help of Evangelical [Lutheran] minister Gábor Sztehlo, who was head of the Red Cross child rescue program in Budapest. As an official employee of the Red Cross, Margit was allowed to leave the designated house and survived the siege of Budapest in children's homes established in confiscated apartments. We know nothing of the family from that point onward except for the important fact that Margit, her parents and presumably her husband all survived. Unfortunately, we do not know the name of Margit's husband to whom she dedicated her typescript as she always addressed him by his nicknames, Pippancs ['Peepkin'] or Kispipi ['Little Peep'] and only mentions that her husband attended the Fasor Evangelical [Lutheran] High School. Neither do we know when he was baptized, but he was originally classified as an Israelite by the Anti-Jewish laws and may have been the influence behind Margit's turn to the Evangelical [Lutheran] faith. Unfortunately, we do not know the date and place of Margit and her husband's conversion as the pertaining church registers are still missing, but based on the Hungarian census and Margit's text, we may assume that she converted after 1941 and before March 1944. When she mentions her parents' conversion to Roman Catholic faith, she subtly hints at the fact that she and her husband had converted to Evangelism [the Lutheran faith] by that time:

I would have liked for them to convert to our faith or at least become Calvinists, but Éliás [Calvinist minister József Éliás] and company rejected us completely and so did ours, or at least they are making this process much more difficult and longer than the Roman Catholics (38-39).

[Szerettem volna, ha a mi vallásunkra térnek át, vagy legalább reformátusra, de Éliásék kereken elutasítanak, a mieink szintúgy, vagy legalábbis sokkal jobban megnehezítik és hosszadalmasabb a folyamat, mint a katolikusoknál]

\section{Trauma, Identity and Narrative}

Margit focused actively and intensively on writing down her personal experiences of the Holocaust, as evidenced by the fact that she wrote an introductory letter to her husband on March 6,1945 , concluded her memoirs in mid-April, and finished her entire manuscript by the end of May. The fact that she wrote her text at such a rapid pace is significant in itself. Psychological 
Kunt, Gergely. "Ironic Narrative Agency as a Method of Coping with Trauma in the Diary-Memoir of Margit K., a Female Holocaust Survivor." Hungarian Cultural Studies. e-Journal of the American Hungarian Educators Association, Volume 7 (2014): http://ahea.pitt.edu DOI: 10.5195/ahea.2014.137

research, primarily the work of James W. Pennebaker has long noted the role and importance of post-trauma narration and writing (Pennebaker 1997), which allowed Margit to communicate the events to her husband so as to aim for no longer having to bear her pain alone. She concluded her diary in April with the following words: "Siege diaries are bad, but it still feels good that I wrote down a ton of things that had been weighing me down and got them out of my system. Try reading between the lines! Bye bye, Little Peep, I will stop now!" [Rossz az ostromnapló, de azért mégis jó érzés, hogy megírtam és kiadtam magamból egy csomó dolgot, ami megfeküdte a gyomromat. Próbálj mögéjeolvasni! Szervusz Kispipi, én most abbahagyom!] (274).

Post-trauma narratives are generally characterized by lack of coherence and fragmentation that gradually become more coherent as the author seeks and then gives meaning to events, allowing them to attribute a message or meaning to their loss so it could be more easily integrated into their life history, but Margit's text is remarkably coherent and not as fragmented as the majority of immediate post-trauma narratives. For survivors of trauma, writing plays a key role in processing experiences, and narratives inspired by trauma are often characterized by mitigating mechanisms, such as humorous anecdotal episodes that obscure the experiences of actual events (László 2008, 124). Although we do not know for certain how Margit composed her text, we may presume that its coherence stems from the fact that what we have access to is the final, edited version of a text that presumably had previous versions and fragmented drafts, and due to the fact that Margit only had access to a typewriter from the first half of March. Since the Russians had confiscated all typewriters from the bank where she had worked, it is highly probable that the diary also had a previous handwritten version, and that Margit was obliged to write her diary by hand from mid-February until March. Nevertheless, no drafts have been found to date and their existence remains no more than speculation.

Although Margit's typescript is unusually coherent for a post-trauma narrative, her memoirs are a testament to the fact that her personal experiences and memories of the Holocaust had fundamentally shaken her identity and were irreconcilable with her life history before the German occupation, resulting in a narrative in which she attempted to reconcile her previous life narrative with her traumatic experiences. The creation of a coherent life narrative plays a fundamental role in the formation and articulation of one's identity (Ricoeur 1988, Ricoeur 1991, 73-81, Schachter 1996, 73), and in Margit's case, this life narrative was separated into a memoir focusing on the past and a diary focusing on the present following the liberation of Budapest in February, 1945. Margit herself notes the temporal difference between the two, since she only started keeping a diary from February 11, 1945:

"Unfortunately, all I can give you is a posthumous diary, at least in part. I only began writing things down on a daily basis in the last days of the siege, so a lot of tiny details will be lost to you, and it's a shame too because they would have made it more real and it wouldn't taste like literature (please forgive me just this once!)" (4)

[Sajnos, csak posthumus naplóval szolgálhatok, legalábbis nagy részben. Naponta mindent azon frissiben feljegyezni csak az ostrom utolsó napjaiban kezdtem, és így sok apró részlet elvész számodra, amikért azért kár, mert igazibbá tették volna az egészet és nem lenne ilyen irodalomízü (nézd el nekem ezúttal!)]. 
Kunt, Gergely. "Ironic Narrative Agency as a Method of Coping with Trauma in the Diary-Memoir of Margit K., a Female Holocaust Survivor." Hungarian Cultural Studies. e-Journal of the American Hungarian Educators Association, Volume 7 (2014): http://ahea.pitt.edu DOI: 10.5195/ahea.2014.137

In her memoirs, Margit selected the events pertaining to her and her milieu carefully and systematically, an arrangement that was also justified by the genre since a memoir allows greater freedom in selecting specific events from the past than a diary, which is more narrowly defined by the time period it allegedly represents.

Margit's introductory letter to her husband states her reasons for writing her memoirs and diary and dedicating them to him, describing the rupture of her life narrative brought on by traumatic experiences as caesura-komplexum ['caesura-complex'], a term she coined by apparently confusing the words komplexus ['fixation'] and komplexum ['complex']. Her explanation reads as follows:

Now as you may have already heard, many things have happened: to me, Budapest, Jews, Hungary, etc., that cannot be considered small or insignificant, and I gradually developed what I refer to briefly as the caesura-complex, and I shall explain immediately what it means. I'm very certain that this year has brought you to a halt as it did me. This year had cut me off sharply and now everything is completely different and I'm different too. I'm sure you feel the same way? The most important part of the caesura-complex is: fear of whether the new Little Hive and the new Gregi [her husband's nickname] will be acceptable to each other?

['Most, mint talán értesültél is róla, történt egy s más: velem, Budapesttel, zsidókkal, Magyarországgal stb., ami sem kicsinek, sem jelentéktelennek nem mondható, és lassanként kifejlödött nálam az, amit röviden caesura-

komplexumnak neveztem el, és mindjárt meg is fogom magyarázni, hogy az mi. Egészen bizonyos, hogy Nálad is ez az év cezurát csinált, éppúgy, mint nálam. Engem ez az év élesen levágott és most valami egészen más van és más vagyok én is. Bizonyára Te ugyanígy vagy? A cezura-komplexum leglényegesebb része: a félelem, hogy az új Kiskas és az új Gregi meg fognak-e felelni egymásnak vajon?’] (1).

While Margit's coined term caesura-komplexum ['caesura-complex'] is incorrect due to the confusion of the words komplexus ['fixation'] and komplexum ['complex'], the function of coinage is significant inasmuch as it allowed her to name and summarize her fears brought on by her separation from her husband and the rupture in her life narrative due to her traumatic experiences of the Holocaust. In the excerpt cited above, she used the adjective "new" to refer to both herself and her husband, which means that she realized both of them had been fundamentally altered during their period of separation due to their experiences of the Holocaust. She expressed her fear that their old identities and relationship could no longer correspond to their new selves by using the verb "cut off" to denote an irreversible process, where the action of cutting can also imply the infliction of a wound, which is the original meaning of the Greek word trauma. Using the verb in this sense is further confirmed by the attributive structure "cut me off sharply" to suggest no continuity between the old and new selves that left both Margit and her husband with ruptured and irreconcilable life narratives. Due to the persecution of Jewish residents and the siege of Budapest, Margit was forced to reconstruct her life narratives in order to be able to integrate the time period covered by the typescript and her experiences into her life history in order to process her trauma and share her burden with her husband. 
Kunt, Gergely. "Ironic Narrative Agency as a Method of Coping with Trauma in the Diary-Memoir of Margit K., a Female Holocaust Survivor." Hungarian Cultural Studies. e-Journal of the American Hungarian Educators Association, Volume 7 (2014): http://ahea.pitt.edu DOI: 10.5195/ahea.2014.137

Although Margit's introductory letter to her husband makes it clear that the Holocaust was a traumatic experience for her, she attempted to process her trauma by constructing a euphemistic, mitigating narrative, a striking example of which is her ironic enumeration of eleven negative experience that she claims did not happen to her between April 1944 and February 1945. Such narrative devices inform us that, right from the beginning, Margit attempted to recount her experiences of an untellable period by constructing humorous stories and using ironic language, thereby shifting the focus from the original, painful, and cruel experiences:

Peepkin, listen well: not only have I survived this whole abomination, but: I had never been dragged away by anyone anywhere, nobody had ever beaten me, I was never put in a labor camp, internment camp or ghetto, never seen a member of the Arrow-Cross up close, none of my nearest relations have been hurt, I had not known starvation in the strictest sense of the word, had not been screwed by Russian soldiers, I wasn't sick and never even caught a measly cold this whole time, I don't even have a single scratch from shrapnel to show for it (3).

[Pipusom, jól figyelj ide: nemcsak hogy élve úsztam meg ezt az egész disznóságot, hanem: soha senki sehova el nem hurcolt, soha senki meg nem vert, nem voltam munkatáborban, nem voltam internálótáborban, nem voltam gettóban, nyilast közelröl nem láttam, egyetlen közelimnek sem esett baja, szó szoros értelmében vett koplalást nem ismertem eddig még, orosz katona nem izélt meg, nemhogy beteg, de még csak náthás sem voltam egész idö alatt, még csak egy repeszdarab okozta karcolást sem tudokfelmutatni].

In writing her memoirs and diary, Margit acknowledged not only the rupture in her life narrative and identity brought on by her traumatic experiences of the Holocaust, but also the idea that the period of the German occupation she was supposed to write about was fragmented and untellable without deliberate and selective restructuration. Her preoccupation with the idea that she would be unable to share her experiences with her husband is evident not only in the coinage of the term caesura-komplexum discussed above but also in her introductory letter in which she writes: "you might ask one day: what happened, how were things, tell me about this year. And then I would just stand here unable to tell you" [...egyszer csak megkérdezed: mi volt, hogyan volt, meséljem el ezt az esztendöt. És akkor itt állok és nem tudok mesélni] (1). It is obvious that, at the time of writing her introduction, Margit considered her memories of persecution as something that cannot be articulated: "How could I possibly tell you and what do I even tell you..." [Mert hogyan meséljem el, mit meséljek...] (1).

Although Margit admits in her introductory letter that her experiences of the Holocaust are difficult to narrate and even refers to her memories in another section as a vast jungle or a seven-volume adventure novel that cannot be told even when broken down into smaller segments, she does provide a structure for her memoirs in order to facilitate her narration of the personal, untellable history of the Holocaust. She divided the traumatic period between April 9, 1944 and February 23, 1945 into eight segments or chapters of different lengths. They are as follows: Az Egymás Után Zuhogó Pofonok Korszaka ['The Period of One Blow After Another']; $A$ "Csillagos Ház"-ban (Miksa utca) ['In the "Starry House" (Miksa Street)' in which what she refers to as 'starry houses' were designated apartments marked with the Star of David in Budapest where Jewish residents were forced to move from their homes]; Október 15. és vidéke 
Kunt, Gergely. "Ironic Narrative Agency as a Method of Coping with Trauma in the Diary-Memoir of Margit K., a Female Holocaust Survivor." Hungarian Cultural Studies. e-Journal of the American Hungarian Educators Association, Volume 7 (2014): http://ahea.pitt.edu DOI: 10.5195/ahea.2014.137

['October 15 and Its Country', October 15 being the date of the Arrow-Cross's rise to power]; Bujdokolok ['I'm Hiding']; Nemzetközi Vöröskereszt és a Kiskas ['The International Red Cross and the Little Hive']; Ostrom ['Siege']; Buda halála ['The Death of Buda'], and finally, Pest ['Pest'] where she recounts the end of the siege on Buda, her own liberation, and her crossing over from Buda to Pest to find her parents. The first six chapters contain her memoirs while the last two chapters contain her diary entries.

\section{The Memoirs}

Margit's memoirs are first and foremost characterized by the use of ironic word compositions to reduce the tragic and solemn nature of her post-trauma narrative of the Holocaust. For instance, she referred to the lunches prepared specifically for Jewish employees at her workplace as a starry meal ['csillagos ebéd'], to the Jewish curfew as starry free time ['csillagos szabadidö'], and called the phenomenon of Jewish residents being forced to wear the Star of David starfestation ['elcsillagosodás'], even though the Hungarian word csillag ['star'] primarily stands for celestial bodies rather than the Star of David. This ironic double wordplay can also be understood in the case of the invented word elcsillagosodás ['starfestation'] to mean the approaching darkness that began in April 1944. Similarly, Margit refers to the introduction of regulations on wearing the yellow star as the premier of the stars ['csillag premier'], to the clothes she wore during the siege as a siege gown ['ostromdressz'] and to the siege of Budapest as the Great Dance ['Nagy Tánc'] or the Great Hoopla ['Nagy Hecc'], the latter two terms likely inspired by the fact that World War I had often been referred to as Nagy Háború ['the Great War'] in Hungary. These ironic word compositions allowed Margit to euphemize and mitigate the events of the traumatic period and facilitated the narration of her memories.

In addition to creating the word compositions discussed above, Margit also discusses horrible events and the trials of the Holocaust with scathing irony and liberal use of euphemistic, mitigating language to describe the period of the German occupation of Hungary as a series of trifling and ridiculous events. Omissions and the denial of negative experiences are especially telling of the depth of Margit's trauma, which she attempted to mask by ironic language use and sarcasm. Had she reported the pain of victims with compassion and empathy, not only would she have contradicted her intentions of writing a mitigating narrative of the past, she would have been forced to acknowledge her losses and the repetition of those losses in writing, enforcing the traumatic meaning of her experiences instead of allowing them to be reintegrated into her life narrative. Therefore, in order to process her trauma, she emphasized in her memoirs that her narrative was not a sufferer's narrative and the described period of her life was not perceived as persecution. Denying the painful horrors of the events she witnessed became part of Margit's unique defense mechanism that allowed her to narrate the events unfolding in Budapest at a safe distance. For instance, during the Budapest terror of the Hungarian Arrow-Cross, many Jewish residents were shot into the Danube, an event Margit described as follows:

$[\mathrm{M}]$ any innocent people have fallen victim, but my impression of the entire Arrow-Cross coup was that it wasn't serious. It felt like when children play Cowboys and Indians. I think this was one of the reasons I couldn't be afraid of it. I am certain that the Germans themselves were in stitches at the Arrow-Cross because they had done the whole thing so immensely idiotically: they were scaring the Jews with a great hoop-la and lots of rattling but in effect they didn't do anything (60). 
Kunt, Gergely. "Ironic Narrative Agency as a Method of Coping with Trauma in the Diary-Memoir of Margit K., a Female Holocaust Survivor." Hungarian Cultural Studies. e-Journal of the American Hungarian Educators Association, Volume 7 (2014): http://ahea.pitt.edu DOI: 10.5195/ahea.2014.137

[...sok ártatlan ember esett áldozatul, az egész nyilaspuccsról az volt a benyomásom, hogy nem komoly. Olyan volt, mint amikor gyerekek indiánosdit játszanak. Azt hiszem, ez is egyik oka volt, hogy nem tudtam félni töle. Biztosra veszem, hogy a németek is halálra röhögték magukat nyilasékon, oly végtelen hülyén csinálták az egészet: hagy hühóval, sok puskapuffogtatással ijesztgették a zsidókat és tulajdonképpen semmit nem csináltak].

Many Jewish residents had fallen victim to the German occupation of Hungary in the period covered by Margit's memoirs, but in her narrative, she attempted to describe the deaths she heard of or witnessed as seemingly insignificant, even in the case of family members, such as Margit's aunt who had committed suicide when she was forced to leave her villa in Rózsadomb ['Rose Hill'], one of the wealthiest districts of Buda. In her words, "The fate of my poor aunt Böske is a special thing: we have known that she would meet a tragic end sooner or later" [Szegény Böske néném esete speciális dolog: róla tudjuk, hogy elébb-utóbb úgyis tragikusan végezte volna] (15). Presenting her aunt's tragic death as predictable makes it seem as though Margit and her family had expected aunt Böske to take her own life regardless of any tragedies unfolding around them. Nevertheless, the second half of Margit's narrative contradicts this idea once the cause of the aunt's death is presented in greater detail and we are informed that the aunt committed suicide in her own home before she would have been forced to leave it. Margit then recounts the funeral of her aunt Böske and ironically focuses on her positive impressions as though her aunt had been more sympathetic to her in death, which is another example of ironic narration intended to mitigate her own losses. She attempts to present the day when her aunt was laid to eternal rest at the Farkasrét Cemetery as an ideal day, although it is clear that the author is displeased by her own attempts to narrate the events in this particular manner:

[I]n the Farkasrét Cemetery, the weather is just beautiful, it's nice and quiet out here, no announcements, no posters, no German soldiers, and I'm sorry my dear Pipus, but I have to emphasize that the birds are singing beautifully because all of this adds to the horribleness of the entire thing. The cemetery is like a factory: they are churning out funerals left and right (16).

[a Farkasréti temetőben, gyönyörü szép az idö, szép csendes odakinn, semmi plakát, semmi falragasz, semmi német katona, és ne haragudj édes Pipusom, de ki kell emelnem, hogy a madarak gyönyörüen énekelnek, mert mindez hozzátartozik az egésznek a szörnyü voltához. A temetöben nagyüzem van: futószalagon temetnek].

Treating the death of Jewish victims in her memoirs as insignificant suggests that Margit attempted to present herself as someone unaffected by the horrors of the German occupation of Hungary, an active agent rather than a passive victim or sufferer of her circumstances as shown by her frequent references to the lucky streak inherited from her ancestors that she referred to as Spielbergerism ['spielbergerizmus']. To create a positive self-image, Margit endowed herself with all the traits of a capable protagonist, including her instincts that she claimed she inherited from her ancestors to whom she refers twice in her memoirs as "Spielbergers" (one of the mountains of Brno is called Spielberg). It is worth noting here that although there are 
Kunt, Gergely. "Ironic Narrative Agency as a Method of Coping with Trauma in the Diary-Memoir of Margit K., a Female Holocaust Survivor." Hungarian Cultural Studies. e-Journal of the American Hungarian Educators Association, Volume 7 (2014): http://ahea.pitt.edu DOI: 10.5195/ahea.2014.137

considerable differences between the memoirs and the diary in terms of their narrative methods and themes, the ancestors and frequent mentions of them can be found in both parts. Spielbergerism in Margit's use seems to mean "lucky deuce," but there are apparent contradictions between various instances of her use of the term. For instance, Margit mentions in her introduction that upon leaving for labor service in April 1944, her husband told her to "Do your best to stay alive, alright?" [Igyekezz életben maradni, jó?] (2), to which she added, "Well I certainly did my best by suspending all Spielbergisms" [Hát én igyekeztem is, minden spielbergerizmust felfüggesztve] (2). Such use suggests that Margit's inherited instincts were detrimental to her survival, but a few lines later she recounts all the traits that aided her survival and mentions her ancestral instincts in fourth place: "the traditional Spielberger-deuce that always takes a sudden lucky turn whenever there is something vital going on" [a hagyományos Spielberger-pechnek, amely mindig szerencsére fordul át hirtelen, mihelyt életbevágó dolgokról van szó] (3). Similarly, in the diary part of the typescript where she describes the Arrow-Cross reign of terror, the characteristics and ways of thinking attributed to Margit's ancestors were momentarily suspended and forgotten, but this too had aided her survival. "Through the entire hoopla, it felt as though Spielbergism had peeled off me, I never thought of how things might turn out" [Az egész hecc tartama alatt a spielbergerizmus mintha lehámlott volna rólam, nem is gondolkoztam rajta, hogy mi lesz] (149).

In order to keep the positive tone of her memoirs, Margit used humor, mitigating language and ironic rhetoric to construct episodes relating to certain discriminatory measures against yellow star-bearing Jewish residents where the outcome of such measures was shown as working in her favor rather than as degrading, humiliating aspects of her life, such as the separately-prepared lunches for Jewish employees that she referred to as the starry meal ['csillagos ebéd']. They were served these special means at the Hungarian General Loan Bank as well, and Margit notes at one point that it was "delicious sour-cream potato stew while the Aryan colleagues got potato paprikash" [finom tejfeles burgonya volt, ugyanakkor, amikor 'árja' kollégák paprikás krumplit kaptak] (8). The potato paprikash was actually horribly spicy and Margit capitalized on this instance to present the discriminatory measure as though it had achieved the reverse effect and concludes her ironic interpretation of these different lunches by saying, "There have been very comical situations in which I often offered to lend my star to a colleague, reassuring them that I would gladly switch when I saw how longingly they stared at the Jewish meal" [Komikus helyzetek adódtak, sokszor ajánlottam fel egyik-másik kollégának kölcsön a csillagomat, biztositva öt, hogy szívesen teszem, amikor láttam, milyen sóvárogva nézi a zsidóebédet $]$ (9).

From the perspective of the present analysis, the actual Jewish menu Margit was served is irrelevant or at least far less significant than the way Margit chose to write about it. According to the timeline of her memoirs, Margit had "starry meals" for three months between April and June, but she only mentions two examples from this period, both of them as if they were positive, which results in a narrative that mitigates and downplays the severity of these discriminatory measures and the humiliation of segregation at the work place. Her omissions and ways of presenting the two positive examples allows her to conclude that the "starry meal" was better not just in her personal opinion, but also that it was confirmed by her non-Jewish colleagues.

One of the narrative strategies of Margit that allowed her to present herself in her memoirs as an active, positive protagonist was structuring episodes of her life narrative in ways that converted negative experiences into positive triumphs over systemic oppression, such as standing up for herself when she was harassed on the street in Budapest. To mitigate the 
Kunt, Gergely. "Ironic Narrative Agency as a Method of Coping with Trauma in the Diary-Memoir of Margit K., a Female Holocaust Survivor." Hungarian Cultural Studies. e-Journal of the American Hungarian Educators Association, Volume 7 (2014): http://ahea.pitt.edu DOI: 10.5195/ahea.2014.137

humiliation of persecution, she recounts an episode where she was walking down the street when a drunken man mockingly told her:

"The lady has a lovely streamlined star!" To which I smile sweetly and grab the corner of the star and reach it towards him saying, "Do you want it? I can give it to you if you fancy it so much!" The man falls completely out of role, awkwardly mutters something like he doesn't need it because he's thankfully not a Jew and quickly hurries off (44-45).

["Szép áramvonalas csillagja van a kisasszonynak!” Én kedvesen mosolyogva megfogom a csillag csücskét és nyújtom feléje: "Akarja? Magának adom, ha annyira tetszik!'” Az ember teljesen kipottyan a szerepéböl, valami olyasmit motyog zavartan, hogy neki nem kell, mert ö hál’ Istennek nem zsidó és gyorsan odébbáll].

Margit's description shows her pride in her witty retort and resourcefulness that allowed her to emerge from the conflict as the victor, thereby reinforcing a positive self-image and presenting herself to her reader(s) as an active agent rather than a passive sufferer.

Despite the narrative methods and rhetorical strategies discussed above, which all served to produce a euphemistic and ironic narrative, Margit's memoirs do betray the deeply traumatic nature of her past by the conspicuous absence of negative episodes and any mention of Margit's own humiliation and suffering, which by no means indicates that there had been no such instances but rather that her narrative serves as a unique defense mechanism. Margit purposefully created a narrative devoid of horror in order to construct a new past of carefully selected anecdotes that shifted the focus away from the pain and suffering of the period comprised in her memoirs, which also facilitated her remembrance of painful events. According to Sándor Bazsányi, one of the most important rhetorical methods of approaching trauma with euphemism in narrative and language use is through irony, which resulted in striking similarities between Margit's narration of her persecution and Imre Kertész's novel Sorstalanság ['Fatelessness'] (Bazsányi 2007, 189-199). In other words, Margit recounted her persecution and the siege of Budapest as her own success story rather than a narrative of suffering, and such an interpretation is justified inasmuch as Margit and her parents managed to survive the Holocaust.

\section{Margit K.'s Diary}

In Margit's typescript, her memoirs are followed by a section that contains her actual diary kept from February 11, 1945; that is, from the end of the siege of Budapest until mid-April 1945 , and since the original manuscript has not been found, we can only presume that she had edited it thoroughly before she included her diary after the memoirs to which it stands in sharp contrast in terms of narrative methods and language use. Margit began keeping a diary shortly after the Soviet troops had occupied the entire capital of Budapest at the cost of incredible damage and civilian casualties, and made a clear distinction between her memoirs and her diary as shown by the following remark: "This is where the posthumous diary ends and I give the floor over to the real one" [Itt véget ér a posthumus napló és átadom a szót az igazinak] (195). The euphemizing narrative methods used in the memoirs disappear entirely in the diary and the themes discussed in the diary are also different, which shows the advantages of constructing a desired past within the genre of the memoirs in contrast to the more strictly defined genre of 
Kunt, Gergely. "Ironic Narrative Agency as a Method of Coping with Trauma in the Diary-Memoir of Margit K., a Female Holocaust Survivor." Hungarian Cultural Studies. e-Journal of the American Hungarian Educators Association, Volume 7 (2014): http://ahea.pitt.edu DOI: 10.5195/ahea.2014.137

diary-writing. There are enormous differences between the two parts, which clearly shows that when we consider daily events, the siege of Budapest and the period of persecution were not as bearable for Margit as her memoirs' descriptions suggest. In my analysis of the memoirs, I have mentioned ironic word play as one of Margit's narrative strategies of mitigation, but when we compare the memoirs to her diary, it becomes clear that these ironic word compositions were all constructed after the fact. While in the manuscript volume the memoirs precede the diary entries, none of Margit's word compositions appear in the diary except "siege gown" [ostromdressz], which shows that in processing the traumatic period in her life, mitigating painful episodes and using irony were only possible in retrospect. In reality, the period of danger during World War II may have been even worse than the period recorded in the diary since the diary begins after the arrival of the Soviet troops, which to Margit signaled the end of World War II and her consequent liberation from persecution.

While Margit's primary narrative strategy in her memoirs was to omit negative events, construct episodes with positive outcomes and write of her persecution and the siege of Budapest as a series of trifling and ridiculous events rather than a narrative of suffering, the diary describes death in greater detail since the specificities of the genre forced the author to concentrate on the events of a single day. The resulting difference practically divides the typescript into two parts where the diary entries are far more realistic and horrifying than the memoirs in which Margit was mostly hiding in Buda while working at a children's home operated by the International Red Cross. After siege of Budapest ended, Margit's diary begins and it recounts her attempt to cross over from Buda to Pest to visit her parents, which was made difficult due to the fact that the bridges connecting the two parts had been blown up by the Arrow-Cross. The spectacle of dead bodies was a pervasive experience in the days after the bloody and prolonged siege of Budapest and Margit's diary discusses them in great detail almost every day in the course of her crossing from Buda to Pest.

I sneak a peek at all their faces even though I'd like to turn away and I feel embarrassment and confusion, as though I were committing something indecent and sneaking peeks at something forbidden. I look at their hands, too: all grayish yellow and very dirty. One of their heads is completely shattered, a bloody pulp, the only white to be seen is the glint of his teeth crushed into crumbs. Their expressions are mostly the same, not calm but not suffering, not distorted. Only one of them looks angry, his brows are furrowed and he's snarling angrily. The hand on another one has stiffened into a strange twisted gesture, reminds me of primitive icons (200-201).

[Lopva megnézem mindegyiknek az arcát, pedig szeretnék elfordulni és közben valami kinos zavart érzek, mintha valami szeméremsértö dolgot követnék el és olyasmit lesnék meg, amit nem szabad. Nézem a kezüket is: mindegyik szürkéssárga és nagyon mocskos. Az egyiknek a feje teljesen szét van zúzva, véres pépcsomó, csak a prézlivé zúzott fogai fehérlenek elö. Az arckifejezésük nagyjából egyforma, nem nyugodt, de nem is szenvedö, nem eltorzult. Csak az egyiknek dühös az arca, szemöldöke összehúzva és haragosan vicsorít. Egy másiknak a keze valami fura kicsavart mozdulatban merevedett meg, primitív szentképeken láttam ilyen kézmozdulatot]. 
Kunt, Gergely. "Ironic Narrative Agency as a Method of Coping with Trauma in the Diary-Memoir of Margit K., a Female Holocaust Survivor." Hungarian Cultural Studies. e-Journal of the American Hungarian Educators Association, Volume 7 (2014): http://ahea.pitt.edu DOI: 10.5195/ahea.2014.137

The scene described above must have deeply shocked Margit, as evidenced by the fact that her daily diary entries are rife with deeply ingrained and disturbing imagery.

Although Margit's memoirs and diary are vastly different in terms of themes and narrative strategies employed, her attempts at presenting a positive self-image and searching for self-definition remains consistent throughout her typescript, in which she described herself in any situation as someone who was always safe from harm. Whether her positive self-image stemmed from the mere desire to be self-confident and self-assured or was truly an accurate portrayal of her at the time is unfortunately unknowable. At any rate, Margit made a point to distinguish herself from her fellow Jewish women in hiding, who had been affected by the antiJewish laws and were subsequently deeply shaken by the not unjustified fear that the Soviet troops occupying Hungary might rape them. As she writes, "The women are especially grieved by the idea that our Russians not only disrespect the Red Cross but also that someone is a Jew and-according to them-has suffered a lot" [A nök rendkivül el vannak keseredve afelett, hogy oroszaink nemcsak a Vöröskeresztet nem respektálják, hanem azt sem, hogy valaki zsidó ésszerintük-sokat szenvedett] (207-208). In this excerpt, Margit clearly presents herself as someone who did not suffer the same apprehensions and did not share the views of the group as shown by the fact that she refused to identify with the narrative of suffering among members of her community. We may also regard this particular instance as a case of denial where Margit's trauma may have been so deep and distressing that it was easier for her to deny its existence.

\section{Conclusion}

Hungarian Jewish citizen Margit began writing the narrative of her traumatic experiences of the Holocaust in March 1945 following the siege of Budapest and constructed a text comprised of an introductory letter, a lengthy memoir, and a shorter diary segment. By recounting her personal experiences of the period, Margit attempted to recreate her narrative identity fragmented by trauma and imbued her text with a meaning that allowed it to be integrated into her life history and altered self-definition. In the memoirs, she recounts the traumatic past by euphemistic, mitigating, and ironic narration of carefully selected episodes with positive outcomes that presumably serve to reinforce a positive self-image, but it is in this very denial of the horrors she had witnessed that the depth of Margit's trauma becomes apparent, since she attempts to write as little as possible of the pain and tragedy of her own persecution. However, the diary following these memoirs is strikingly different due to her detailed daily entries of the everyday horrors following the siege. Margit's narrative strategies in the memoirs clearly show that the horrors of the Holocaust could only be subdued in retrospect by constructing positive stories, thereby mitigating the author's painful memories.

\section{Works Cited}

Bazsányi, Sándor. 2007. “Quintilianus, Szókratész, Auschwitz. Kertész Imre Sorstalanságának iróniájáról” [Quintilian, Socrates, Auschwitz: The Irony of Imre Kertész's novel Fatelessness]. Jelenkor 50 (Feb. 2007): 189-199.

László, János. 2008. The Science of Stories: An Introduction to Narrative Psychology. London and New York: Routledge.

Lejeune, Philippe. 1989. "The Autobiographical Pact” In On Autobiography. Ed., Paul John Eakin. Minneapolis: University of Minnesota Press: 3-30 
Kunt, Gergely. "Ironic Narrative Agency as a Method of Coping with Trauma in the Diary-Memoir of Margit K., a Female Holocaust Survivor." Hungarian Cultural Studies. e-Journal of the American Hungarian Educators Association, Volume 7 (2014): http://ahea.pitt.edu DOI: 10.5195/ahea.2014.137

Lejeune, Philippe. 2001. “How Do Diaries End?” In On Diary. Eds., J. D. Popkinand J. Rak. Manoa. University of Hawaii Press:187-201.

Pennebaker, James W. 1997. Opening up: The Healing Power of Expressing Emotions. New York: Guilford.

Ricoeur, Paul. 1988. Time and narrative III. Chicago: University of Chicago Press.

Ricoeur, Paul. 1991. "Narrative identity." Philosophy Today 35 (Spring, 1991): 73-81.

Schacter, Daniel L. 1996. Searching for Memory: The Brain, the Mind, and the Past. New York: Basic Books.

Tengelyi, László. 1998. Élettörténet és sorsesemény [Life Story and Fateful Event]. Budapest: Atlantisz. 